\title{
Well-being and environmental change in the arctic: a synthesis of selected research from Canada's International Polar Year program
}

\author{
Brenda Parlee $\cdot$ Chris Furgal
}

Received: 7 August 2012 / Accepted: 4 September 2012

(C) The Author(s) 2012. This article is published with open access at Springerlink.com

\begin{abstract}
The social and cultural dimensions of arctic environmental change were explored through Canada's International Polar Year (IPY) research program. Drawing on concepts of vulnerability, resilience and human security, we discuss preliminary results of 15 IPY research projects (of 52) which dealt with the effects and responses of northern communities to issues of ecological variability, natural resource development and climate change. This paper attempts to determine whether the preliminary results of these projects have contributed to the IPY program goal of building knowledge about well-being in the arctic. The projects were diverse in focus and approach but together offer a valuable pan-northern perspective on many themes including land and resource use, food security, poverty and best practices of northern engagement. Case study research using self-reported measures suggests individual views of their own well-being differ from regional and territorial standardized statistics on quality of life. A large body of work was developed around changes in land and resource use. A decline in land and resource use in some areas and consequent concerns for food security, are directly linked to the effects of climate change, particularly in coastal areas where melting sea ice, erratic weather events and changes in the stability of landscapes (e.g., erosion, slumping) are leading to increased risks for land users. Natural resource development, while creating some new economic opportunities, may be compounding rather than offsetting such stresses of environmental change for vulnerable populations. While the IPY program has contributed to our understanding of some aspects of well-being in the arctic, many other issues of social, economic, cultural and political significance, including those unrelated to environmental change, remain poorly understood.
\end{abstract}

\footnotetext{
B. Parlee $(\bowtie)$

Faculty of Native Studies, Faculty of Agricultural, Life and Environmental Sciences, University of Alberta, 1-09 Pembina Hall, Edmonton, Alberta T6G 2H1, Canada

e-mail: brenda.parlee@ualberta.ca

C. Furgal

Indigenous Environmental Studies Program, Trent University, 1600 West Bank Dr, Peterborough ON K9J 7B8, Canada

e-mail: chrisfurgal@trentu.ca
} 


\section{Introduction}

The well-being of northern Indigenous peoples has been an important consideration in recent studies on arctic environmental change. The impact of long range contaminants on country/ traditional food systems, warming temperatures and growth in the pace and scale of natural resource development projects are thought to be disproportionately affecting arctic environments and the livelihoods of northern Indigenous peoples (Berkes et al. 2005; Nuttall et al. 2005). Some scholars suggest the extent of environmental disruption may be of limited consequence and concerns paternalistic when compared to the extent of social change experienced since Euro-Canadian settlement (Haalboom and Natcher 2012; Duerden 2004). Others point to federal and territorial statistics on ill health among young and vulnerable northern populations, socio-economic inequities, struggling local economies and land and resource use conflicts as evidence that the ideal of "northern sustainability" has yet to be achieved (Andersen and Poppel 2002; Young and Mollins 1996; Furgal and Seguin 2006; Suluk and Blakney 2009; Abele 2009; Lyons 2010; Oosten and Laugrand 2002; Christensen 2011).

The Canadian International Polar Year (IPY) research program sought to understand more about well-being in the arctic through natural, health and social science research (20072011). Although there are many definitions, well-being in this paper refers to quality of life of northern Indigenous peoples and takes into account both economic and material considerations (e.g., harvesting, housing) as well as the knowledge, practices and beliefs that matter to people's sense of self and community. During the Canadian IPY program, scientists, Indigenous leaders and local community researchers worked together in over 50 different communities across northern Canada (Tables 1 and 2). These projects considered "well-being" through the lens of Indigenous beliefs and such social science theories as vulnerability, resilience and human security. How are contemporary and future patterns of environmental change being interpreted through Indigenous knowledge, practices and beliefs? What are some of the key issues and areas of vulnerability and what further capacities need to be developed to ensure resilience? What kinds of interrelationships (both short term and long term feedbacks) are there between environmental change and community well-being? What are the implications for arctic security?

\section{Context}

Well-being in the arctic refers to the quality of life of Inuit, First Nations, Métis and other northern peoples but has many different definitions depending on the disciplinary lens and cultural context. That being the case, the well-being of Indigenous peoples varies widely within and between communities and regions in northern Canada. It may simultaneously be perceived as stable, improving or worsening in the last several decades (Kruse et al. 2009). Although there are many interpretations, government statistics reveal that many individuals and communities struggle with high levels of unemployment, lack of safe water, limited housing, and physical health problems (e.g., tuberculosis) conventionally associated with the developing world (Bjerregaard et al. 2004; Christensen 2011; Wootton and Metcalfe 2010; Young and Mollins 1996). Such conditions may improve or worsen as the effects of climate change become more apparent and the environmental effects of natural resource development become more widespread. But absolute predictions about the effects of a changing environment on community well-being are difficult or impossible to make. Arctic ecosystems do not behave predictably and anthropogenic changes cannot be easily disassociated 
Table 1 Canadian IPY projects that dealt with aspects of well-being

\begin{tabular}{|c|c|c|}
\hline Project title & Principal investigator & Institution \\
\hline The circumpolar flaw lead system study & David Barber & University of Manitoba \\
\hline Impacts of a changing arctic tree line & Karen Harper & Dalhousie University \\
\hline $\begin{array}{l}\text { Monitoring the impacts of global change on } \\
\text { caribou and wild reindeer and their link to } \\
\text { human communities }\end{array}$ & Don Russell & Yukon College \\
\hline $\begin{array}{l}\text { Environmental change and traditional use in } \\
\text { the old crow flats in Northern Canada }\end{array}$ & Shel Graupe & $\begin{array}{l}\text { Vuntut Gwitch'in } \\
\text { First Nation }\end{array}$ \\
\hline Northwest territories ice patch study & Thomas Andrews & $\begin{array}{l}\text { Prince of Wales Northern } \\
\text { Heritage Centre, GNWT }\end{array}$ \\
\hline Inuit sea ice use and occupancy project & Claudio Aporta & Carleton University \\
\hline $\begin{array}{l}\text { Inuit history: climatic change and historical } \\
\text { connections in arctic Canada }\end{array}$ & Patricia Sutherland & Canadian Museum of Civilization \\
\hline $\begin{array}{l}\text { Constructed wetlands for treatment of wastewater } \\
\text { in arctic communities }\end{array}$ & Brent Wootton & Fleming College \\
\hline Dynamic inuit societies in arctic history & Max Friesen & University of Toronto \\
\hline $\begin{array}{l}\text { Engaging communities in the monitoring } \\
\text { of country food safety }\end{array}$ & Manon Simard & Makivik Corporation \\
\hline Communities in the changing arctic & Barry Smit & University of Guelph \\
\hline $\begin{array}{l}\text { The impacts of oil and gas activity on peoples } \\
\text { in the arctic }\end{array}$ & Dawn Bazely & York University \\
\hline $\begin{array}{l}\text { Kwaday Dan Ts'inchi discovery - expanding our } \\
\text { understanding through linked scientific and } \\
\text { community studies project }\end{array}$ & Sheila Greer & $\begin{array}{l}\text { Champagne and Aishihik } \\
\text { First Nations }\end{array}$ \\
\hline $\begin{array}{l}\text { Traditional knowledge and climate change in } \\
\text { Tr'ondëkHwëch'in traditional territory }\end{array}$ & Allie Winton & Trondek Hwech'en \\
\hline Arctic peoples, culture, resilience and caribou & Cindy Dickson & Council of Yukon First Nations \\
\hline
\end{tabular}

from natural variabilities. Communities are also complex and not passive in responding to changes in their environment (Duerden 2004). Nor are communities homogeneous in their interpretations and responses. The International Polar Year program aimed to embrace this complexity through social science research across northern Canada.

The Yukon is the most westerly of Canada's territories and comprises a population of 35,944 people (2012), over 27,000 of whom live in the capital city of Whitehorse. Within this population, $25 \%$ identify themselves as First Nations, Métis or Inuit. Yukon First Nations include the Southern and Northern Tutchone, Tlingit, Tagish, Kaska, Tanana, Han

Table 2 Cost of northern food basket for selected northern communities (Furgal 2010)

\begin{tabular}{llll}
\hline Location & Cost of perishables $(\$)$ & Cost of non-perishables (\$) & Cost of total food basket (\$) \\
\hline Nain, LB & 90 & 106 & 196 \\
Kuujjuaq, QC & 92 & 129 & 220 \\
Pangnirtung, NU & 127 & 165 & 292 \\
Paulatuk, NT & 180 & 167 & 343 \\
Old Crow, YT & 169 & 219 & 388 \\
Edmonton, AB & 65 & 108 & 173 \\
\hline
\end{tabular}


and Gwich'in people. Inuvialuit peoples' traditional hunting grounds also include northern Yukon. In 1990, the Government of Canada, Government of the Yukon and Council of Yukon First Nations finalized a land claim agreement (Yukon Umbrella Final Agreement) which speaks to the rights and interests of 11 First Nations.

The Northwest Territories is home to a population of 41,462 people and comprises an area of $1,183,085 \mathrm{~km}^{2}$. Just over $50 \%$ of the territorial population is Indigenous (composed of more than nine Aboriginal language groups). There are 34 communities in the territory which range in size from almost 20,000 people (Yellowknife) to 45 people. Yellowknife is the largest community and has the largest number of Aboriginal peoples (42\%). The territory is divided into five overlapping land claim settlement areas. In 1984, the Inuvialuit Final Agreement was signed with Canada. The Inuvialuit Settlement Region (ISR) spans 906,430 $\mathrm{km}^{2}$ and includes several sub-regions: the Beaufort Sea, the Mackenzie River delta, the northern portion of Yukon ("Yukon North Slope"), the northwest portion of Northwest Territories, and the western Canadian Arctic Islands. In 1992, the Gwich'in Settlement Area was created after the signing of Gwich'in Comprehensive Land Claim Agreement. The Gwich'in Settlement Area spans 56,935 $\mathrm{km}^{2}$ and includes the communities of Aklavik, Fort McPherson, Inuvik and Tsiigehtchic. The Sahtú Dene and Métis Comprehensive Land Claim Agreement was signed in 1994 which recognized Sahtúgotine interests in over $283,000 \mathrm{~km}^{2}$ of land represented by the communities of Déline, Fort Good Hope, Tulita, Colville Lake and Norman Wells. The Tłịcho agreement covers a 39,000 $\mathrm{km}^{2}$ area between Great Bear Lake and Great Slave Lake. The territory includes the communities of Behchoko, Gamèti, Wekweeti and What'ì. The Deh Cho region is home to fourteen First Nations and Metis communiites. In Akaitcho, there are four First Nations communities including the Yellowknives Dene First Nations (N'dilo, Dettah), Lutsel K'e Dene First Nation, and Deninu Kue (Fort Resolution). In these two regions, land claim settlements, self-government and treaty entitlement negotiations are ongoing with the federal government of Canada.

Nunavut ("our land") covers $1,877,787 \mathrm{~km}^{2}$ of land and $160,935 \mathrm{~km}^{2}$ of arctic seas. The territory includes part of the mainland, most of the Arctic Archipelago, and all of the islands in Hudson Bay, James Bay, and Ungava Bay and the Belcher Islands. The population of 31906 live in 18 communities, largely in coastal areas and are organized in the three administrative regions of Kitikmeot, Kivalliq, and Qikiqtaaluk/Baffin. The majority of the population is Inuit $(83.6 \%)$ with a smaller non-Aboriginal population $(15 \%)$ largely located in the territorial capital of Iqaluit $(15 \%)$. First Nations and Métis make up another $0.34 \%$ and $0.44 \%$ of Nunavut's population.

Nunavik ("place to live") is a 443,684 $\mathrm{km}^{2}$ area located in northern Quebec. Until 1912, the region was part of the District of Ungava of the Northwest Territories. Nunavik is currently home to 11,627 people, over $90 \%$ of whom are Inuit. The majority of people live in 14 villages along the coast and in the Cree reserve of Whapmagoostui near Kuujjuarapik. Inuit of this region call themselves Nunavimmiut.

Nunatsiavut ("our beautiful land") is a $72,520 \mathrm{~km}^{2}$ area of coastal Labrador and is governed by the Labrador Inuit. It also includes $44,030 \mathrm{~km}^{2}$ of sea rights. The region is home to the communities of Nain, Hopedale, Makkovik, Rigolet and Postville and outside of the Labrador Inuit Settlement Area in Happy Valley-Goose Bay and Mud Lake.

Long colonial histories focused on the assimilation of the livelihoods, cultures and societies have left many northern communities without the means to achieve well-being (Royal Commission on Aboriginal Peoples 1996). Colonial social policies aimed at assimilation and sedentarization altered many aspects of the way of life of northern peoples. Although missionaries, whaling and trade associated with the trapping economy had a major influence prior to the $1960 \mathrm{~s}$, it has really been in the last 100 years during which scholars 
speak about real declines in well-being which are attributed to a loss of self-reliance (Billson 2001). Examples include forced relocation of Inuit communities, criminalization of subsistence (e.g., caribou hunting), residential school practices and colonial measures of governance. Other Indigenous peoples in southern Canada, Australia, New Zealand and the United States with similar colonial histories face very similar contemporary issues of poverty and marginalization (Gracey and King 2009).

The growth of mining, hydro-electric development and oil and gas exploration currently visible in many parts of the Canadian arctic and other parts of the circumpolar north have led to many significant changes. Some perceive also the circumstances of Inuit, Dene and Metis of the Canadian north as similar to the experience of Greenland societies in the 1950s and 1960s; the rapid pace and scale of change in Greenland during this period is thought to have resulted in a loss or shift in traditional social norms and values (Hansen 1999). Unlike the Greenland experience, the rapid pace and scale of change in the Canadian north may be outweighing the adaptive capacity of many northern communities (West 2011). There is also concern that climate change is likely to compound the level of socio-economic and cultural stress already being experienced (Smit et al. 2008). However, these views may be overly pessimistic and ironic given the kinds of drastic social changes experienced over the last one or two generations (Duerden 2004). Northern communities are also complex and heterogeneous and likely to experience and respond to both social and environmental stress in very different ways. It is within this context that research was carried out during Canada's International Polar Year.

\section{Theoretical framework: concepts of well-being-what does it mean?}

The concept of well-being refers to a diverse and interrelated set of social, cultural, economic, political and ecological factors that contribute to the quality of life of individuals, families and communities. Similar to health, well-being is simultaneously seen as a state and a process, an outcome as well as an ideal. For other scholars it is the set of tools needed to deal with the stresses and challenges of everyday life (Giri 2000; Diener et al. 1999). Emerging from the disciplines of psychology and sociology, comprehensive studies on patterns of well-being have been carried out in many parts of the world but have been limited in the arctic until recent years (Diener et al. 1999).

Well-being is conceptually linked to other concepts including "quality of life" and "health" in that they refer to similar indicators and determinants (Diener and Suh 2000). Many basic measures aimed at understanding demographic variation in quality of life of Canadians point to a significant gap between Indigenous people and non-Indigenous people in Canada. The First Nations Community Well-being Index suggests well-being among First Nations was markedly lower as measured by such indicators as education, labour force activity, income and housing. Based on 2001 data, nearly $50 \%$ of First Nations communities occupied the lower half of the index range (between 0.30 and 0.65 ) while less than $3 \%$ of other Canadian communities fell within this range (Indian and Northern Affairs Canada 2004, 2010a, b). A historical comparison of trends in the well-being of First Nations, Inuit and other Canadian communities demonstrates the gap that exists between these populations (Figs. 1 and 2). While the gap is decreasing to some degree, there are still marked differences, particularly between First Nations and other communities in Canada (Indian and Northern Affairs Canada 2010a, b).

These kinds of generalized assessments provide only a narrow understanding of Indigenous well-being (Prout 2011; Kral et al. 2011; Parlee et al. 2007). Well-being, like the 


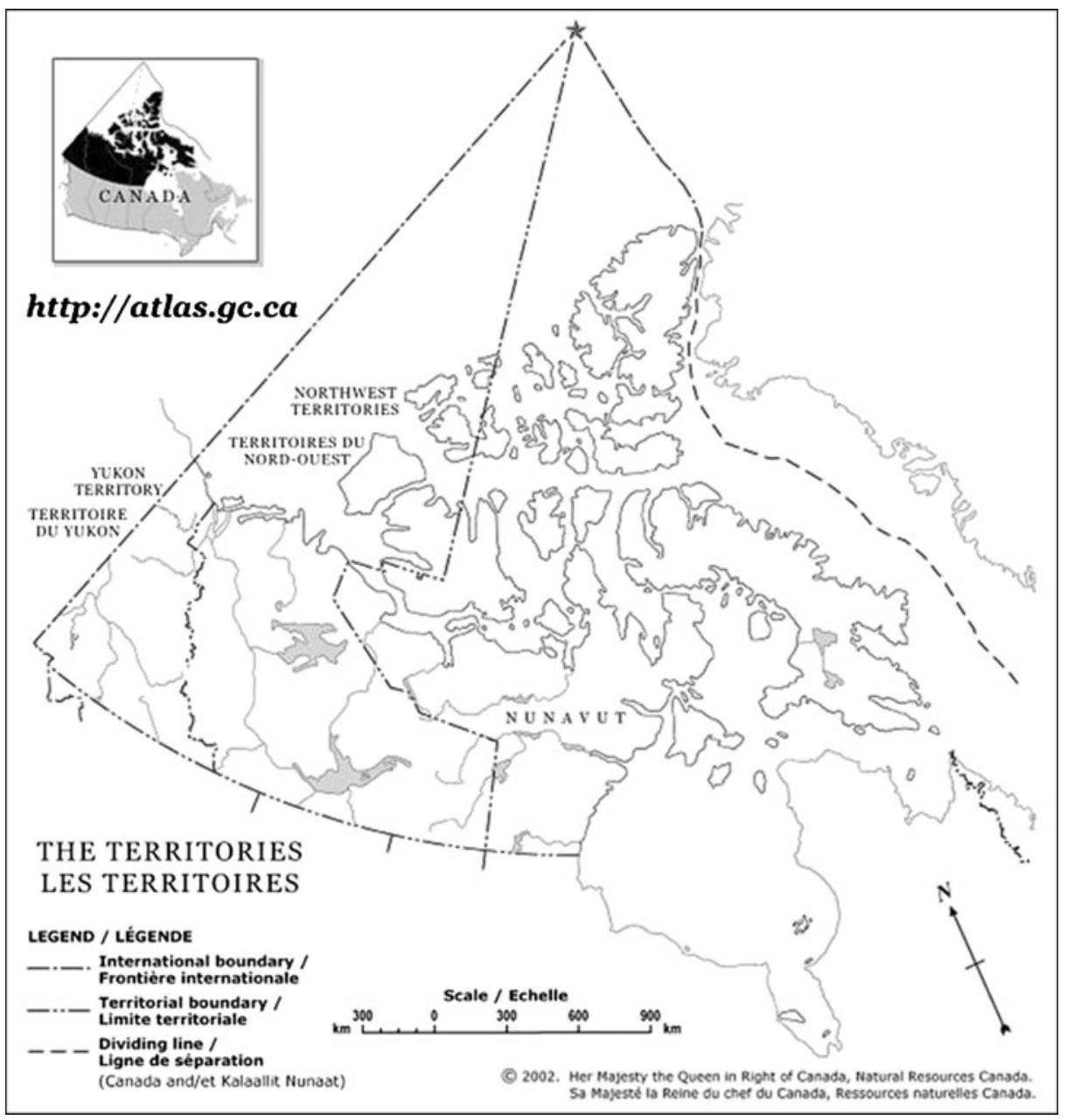

Fig. 1 Map of Northern Canada, locations of case study communities

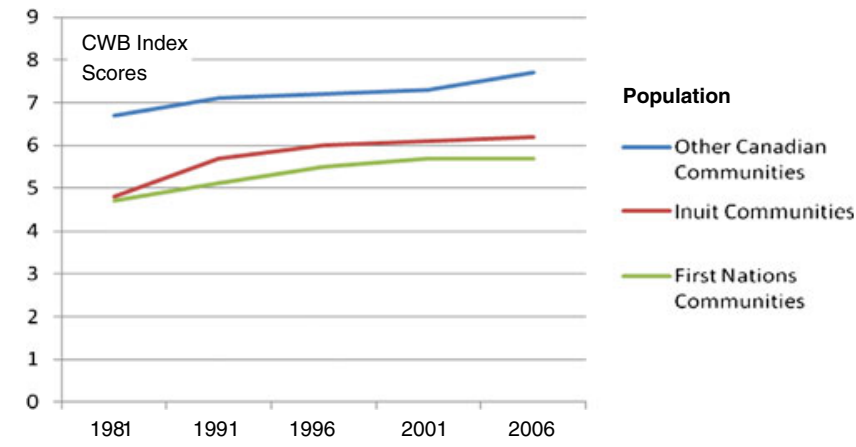

Fig. 2 Historical trends of well-being in First Nations, Inuit and other Canadian communities based on CWB scores (1981-2006). (Indian and Northern Affairs Canada 2010a, b) 
concept of health, is culturally constructed and has many different socio-economic, cultural and environmental dimensions and can be defined and measured by many kinds of indicators (Diener 1996). The concept of well-being is thought be synonymous with many Indigenous peoples' beliefs about wellness and the need for balance between the emotional, mental, spiritual, and physical dimensions of the person in connection to his or her family, community and environment (Royal Commission on Aboriginal Peoples 1996; Gracey and King 2009). Translations of health and well-being such as, "the Dene way of life" or Dene ch'anié and miyupimaatisiiu-being alive well in Cree, provide insight into the cultural specificity of this concept in northern Indigenous communities (Parlee et al. 2007; Adelson 1998).

Many of the indicators and measurements used, developed or explored in large studies have tended to reflect dominant mainstream cultures with little consideration given to the heterogeneity of arctic peoples (Andersen and Poppel 2002; Taylor 2008). There is significant variation in the quality of life or well-being within the Indigenous population, particularly when using alternative indicators of local and cultural significance (Kruse et al. 2009; Usher et al. 2003; Andersen and Poppel 2002). Unlike many generalized approaches to measuring well-being that focus on material, physical and socio-economic indicators, more recent studies, including some of those under the Canadian IPY program have attempted to recognize local cultural beliefs in their conceptualization of both local communities and environments. Many of these beliefs are rooted in Traditional Knowledge (TK). In many parts of the north, including Nunavut and settled land claim areas of the Northwest Territories, TK is to be considered equally with science in decision-making about lands and resources. Legislation such as the Traditional Knowledge Policy of the Government of the Northwest Territories is precedent setting in the opportunities it provides northern Indigenous peoples to influence the decisions of environmental assessment, land use planning and the management of forests, wildlife and fisheries (Abele 1997; Parlee 2012). This cumulative body of knowledge which has developed over many generations, is referred to by different names at the local level. For example, Inuit TK or Inuit Qaujimajatuqangit played a key role in studies led by Claudio Aporta and collaborators on sea ice change and use in Nunavut. Gwich'in Knowledge was an important focus of projects led by the Yukon and the Gwich'in Settlement Region of the Northwest Territories. In addition to providing historical context and ongoing empirical observation, TK is seen as a critical guide in the adaptation and resilience of northern peoples to changing environmental conditions and to our understanding of well-being in the arctic (Berkes et al. 2000).

\subsection{Land and well-being}

While there are many factors that affect the well-being of northern communities, changes in the health of the environment is a significant focus of research in northern Canada. A review of the social science literature dealing with arctic environments reveals numerous characterizations. Economic anthropologists, geographers and ecologists have long focused on ecological diversity and the abundance of edible wildlife and plants as critical to the wellbeing of northern peoples (Berkes 2008a, b; Chapin 2005). Other scholars, influenced by theories of cultural determinism, offer a more simplistic and linear interpretation of humanenvironment relations. As noted by Freilich (1967), many early anthropologists tended to look for a single causal factor to explain social and cultural change with the 'sovereign influence of environment' being of widespread interest to scholars as well as poets, writers and historians (Freilich 1967:26). Increasingly, however, there is greater theoretical interest in the symbiotic relationship between northern Indigenous societies and environments 
particularly in transdisciplinary studies of social-ecological systems and resilience (Bravo 2006; Berkes 2008a, b; Armitage et al. 2008).

In studies related to health and well-being, the environment or "land" tends to be considered as both a benefit and a threat depending on the theoretical lens of investigation (Owens et al., this edition). A significant body of research demonstrates the spiritual significance and therapeutic value of these landscapes and land-based experiences as well as the positive contributions of the land to the economy and health of northern peoples (Wilson 2003; Richmond and Ross 2009). The harvest and consumption of traditional/ country foods is closely associated with feelings of well-being (Kirmayer et al. 2008).

On the other end of the spectrum, arctic environments have been characterized in some ethnographic as well as oral histories as a harsh environment to be respected; lack of respect for the environment, according to some First Nations and Inuvialuit oral histories, can result in great hardship (Steckley 2008; Heine et al. 2001; Condon 1988; Boas 1964). Although development in the north has alleviated some sources of environmental stress and related social hardships (e.g., famines), other kinds of environmentally induced hardships are being created. The bioaccumulation of contaminants presents a variety of stresses on the well-being of northern communities. Although arctic environments have historically been less contaminated than regions closer to more heavily industrialized regions in the south where most pollutants are produced, the north is increasingly becoming a contaminant sink where higher than anticipated levels of persistent organic pollutants (POPs) and mercury can now be found (Furgal et al. 2010). Global recognition of their negative impacts on the health of Inuit and other northern peoples led to variety of measures and agreements to limit contaminant use (e.g., Stockholm Convention) (Downie and Fenge 2003). Resource development including mining, oil and gas exploration, hydro-electric development as well as transportation networking is creating other kinds of stresses for ecosystems and communities. Single resource development projects may, on their own, have only limited impacts. However, the rapid pace and scale of resource development (including many small projects and some very large projects) are by some scholarly and local accounts, resulting in significant, adverse socio-economic and cultural effects (Duerden 2004; Nuttall et al. 2005; Wilson 2003). Some arctic communities are also experiencing unprecedented climatic impacts including increased temperature, extreme weather events, reductions in the extent of ice cover, increases in precipitation, degree and extent of permafrost thaw, coastal erosion, seasonal and multi-year ice thaw (Hinzman et al. 2005; ACIA 2004). "These changes will have serious implications for ecosystems and for people's livelihoods and wellbeing, and they will occur in the context of ongoing social, cultural, economic, and political transformations in northern communities" (Smit et al. 2008:2). It is this dynamic and increasingly unpredictable view of life in northern communities which underpinned many of the IPY projects. In this paper, we specifically investigate whether IPY research on vulnerability, resilience and/or human security have enhanced our understanding of well-being in arctic communities.

3.2 Perspectives on well-being: vulnerability, resilience and human security in the context of arctic environmental change

There are numerous ways of characterizing well-being in the context of environmental change. While not explicitly linking their work to the concept of well-being, research under the IPY program investigated aspects of community and individual vulnerability, resilience and human security. How are these concepts related to well-being? One conceptual interpretation is that vulnerability, human security and resilience are dynamic outcomes of adaptation to ecological changes occurring at many different scales from the global to the 


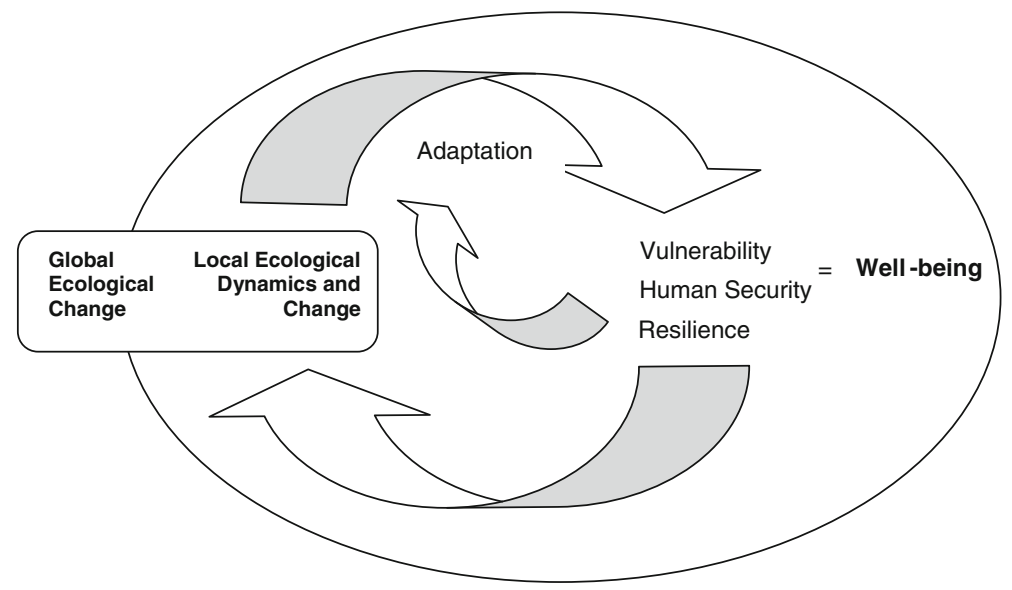

Fig. 3 Linking concepts from IPY research to well-being

local. Such outcomes can have a feedback influence over further kinds of adaptation but also have the potential to influence the course of environmental change (Fig. 3).

\subsection{Adaptation}

A concept used in most of the IPY research on vulnerability, resilience and human security is that of adaptation. In the climate change literature, the term generally refers to those adjustments in natural or human systems made to moderate harm or exploits beneficial opportunities (IPCC 2007). The Arctic Council has also stressed the importance of "taking action to develop and implement local adaptation strategies for Arctic areas". It has been used widely in many studies dealing with both environmental variability and change in northern Canada and elsewhere. Associated terms in the climate change lexicon include adjustment, adaptive capacity and maladaptation. The concept of adaptation is not without its critics. Some Indigenous peoples see it as problematic because of latent associations with historical periods of colonization and assimilation. Other scholars have focused on identifying ways of strengthening or increasing the capacity for individual and community adaptation, particularly at the local level.

\subsection{Vulnerability}

The land has long been considered as a source or contributor to the well-being of northern Indigenous peoples; however, an alternative viewpoint considers the ways in which the environment may be a cause of harm. The IPCC (2007) adopted the definition of vulnerability that states that "vulnerability is the degree to which a system is susceptible to, and unable to cope with, adverse effects of climate change, including climate variability and extremes. Vulnerability is a function of the character, magnitude, and rate of climate change and variation to which a system is exposed, its sensitivity, and its adaptive capacity." Vulnerability in the context of this paper refers to the degree of impact likely to be felt by a given individual, household, community or region as a result of environmental changes. More specifically, vulnerability analyses consider patterns of current or potential environmental hazards (e.g., flooding, forest fire or melting sea ice) and attempt to predict how northern communities may be affected by these hazard events based on the circumstances of individuals, communities and institutions. "This perspective emerged out of recognition that hazards and disasters were not a result of physical events alone, 
but were also greatly influenced by the social, economic, and cultural conditions that contributed to hazardous exposures and the ability to plan for and manage them" (Ford and Smit 2004: 392)

\subsection{Resilience}

Resilience theorists are explicitly or implicitly concerned with the well-being of individuals, families and communities. Although similar to vulnerability and adaptation, resilience is concerned with how people can use their skills and strengths to bounce back from adversity or overcome stresses and challenges whether social, economic or ecological. It is this effort to learn about how to overcome adversity rather than the cause of the adversity which has many scholars involved in Indigenous health research concerned about its growing currency. Nonetheless, it has become part of a common language in a wide range of studies ranging from suicide and addictions to sustainable economic development to arctic climate change (Kirmayer et al. 2011; Forbes 2008; Chapin et al. 2006; Berkes and Jolly 2001). It has roots and use in complex systems and ecology theory which makes it particularly useful as an interdisciplinary and transdisciplinary concept of study and communication about the effects of environmental change. The concept of social-ecological resilience for example, is a way of conceptualizing the interconnections or feedbacks between the resilience of people and the resilience of the environments in which they live. Some plain language meanings emerging from Indigenous communities elsewhere include "adaptation despite high risk", "good development despite high risk", "competence under stress", "recovery from trauma", and "normal development under difficult conditions" (Fleming and Ledogar 2008; Kirmayer et al. 2011). "This new focus on 'community resilience' looks at how people overcome stress, trauma and other life challenges by drawing from the social and cultural networks and practices that constitute communities" (Kirmayer et al. 2011).

\subsection{Human security}

Another means of understanding well-being in the arctic is through research on human security. It generally refers to "safety from such chronic threats as hunger, disease, repressing and hurtful disruptions in the patterns of daily life" (Axworthy 2001). Human security in the arctic is concerned with the intersection of power and governance and the social, economic, political and environmental factors that contribute to the well-being of arctic peoples (Daveluy et al. 2011). It has become a popular concept in arctic policy discourse in Canada as federal and territorial governments seek to maintain sovereignty (i.e., military security) amidst mounting global interest in the mineral, oil/gas, and hydro-electric potential that has risen with melting sea ice in the north-west passage (Borgerson 2008). Among the concepts of greatest currency is that of food security (Huish 2008). The World Health Organization defines food security as existing "when all people at all times have access to sufficient, safe, nutritious food to maintain a healthy and active life". Food insecurity is compounded in the north by high levels of unemployment and higher than average cost of food. Northern Food Basket ${ }^{1}$ costs in the Yukon and Northwest Territories can be $50 \%$ to $100 \%$ higher as in cities in southern Canada (Tables 1 and 2). The concept generally considers both physical and economic factors that limit or facilitate access as well as cultural attributes that determine food preference. In Canada, $21 \%$ of Aboriginal

\footnotetext{
${ }^{1}$ The Northern Food Basket consists of 46 items used as a measure of the cost of living. It developed as a parallel to Agriculture Canada's Canadian Food Basket, and it is used to monitor cost of a nutritious diet for a lower-income reference family of four (a girl 7-9 years, a boy 13-15 years, and a man and woman 2549 years of age).
} 
households are at risk of being "food insecure", however, the statistics are twice as high in some Nunavut communities (Egeland et al. 2011).

\section{Approach}

The International Polar Year was a targeted research program focused on building knowledge on a variety of natural, health, physical and social science themes including community well-being. It was the largest international program of coordinated, interdisciplinary science ever undertaken with focus on both the Arctic and Antarctic (IPY 2011). Building on the successes of previous federal programs such as the Northern Contaminants Program, the Government of Canada established key principles of northern engagement (collaboration, capacity building and knowledge sharing) in IPY research to ensure benefits to northern communities. With many lessons learned, "Canada actively promoted the inclusion, for the very first time in an IPY, a research theme focused on changes in human health, society, culture and resources" (IPY 2011). No single project used "well-being" as the conceptual framework but rather they employed theories of vulnerability, resilience and human security in relation to key issues of environmental change. We use "well-being" here given it was the overarching social science concept used by IPY to discuss research involving or about northern communities. This paper discusses the results of a subset (15) of the 52 IPY projects funded form 2007-2011 to determine what advances in knowledge on community wellbeing were made through the program. Principal Investigators from each of the projects were consulted in the development of the synthesis. Given the multi-disciplinarity and diversity in the 15 studies identified by IPY as related to "well-being", only generalized results of research shared in public documents and final scientific reports to the Government of Canada were considered in this synthesis.

\section{Results: cross cutting insights about well-being in the arctic}

\subsection{Well-being}

The Arctic Peoples, Culture, Resilience and Caribou (ACRC) project aimed to understand "well-being" using community-based research methods, community personnel and normative measures such as self-reported well-being, self-reported health status, self-reported anxiety and confidence in the future. Given small populations and in the interest of protecting the anonymity of participants, the names of the communities are not included here.

Results from one case study community on "stress and anxiety" suggest a situation of poor well-being. However, when asked directly to rate their current state of "health" or "well-being", the message was different with $92 \%$ reporting a good or excellent state of "well-being". The results were similar in another community with a larger number of participants where $90 \%$ of adults $(n=120)$ reported their "health" as good or excellent. Such a profile is consistent with other measures of well-being used including "confidence in the future" where $70 \%$ of adults reported being confident that their children would have a good future.

The well-being of northern Indigenous communities has been shown through previous qualitative research as strongly interconnected with the health of the environment. Spending time on the land is considered to be highly therapeutic or have healing benefits. As described by residents of Paulatuk, and those from many other communities, "going out on the land is what we love to do" (Todd 2010). A further project funded through the ACRC program 
Fig. 4 Relationship between time spent on the land and stress and anxiety in one northern indigenous community $(N=40)$

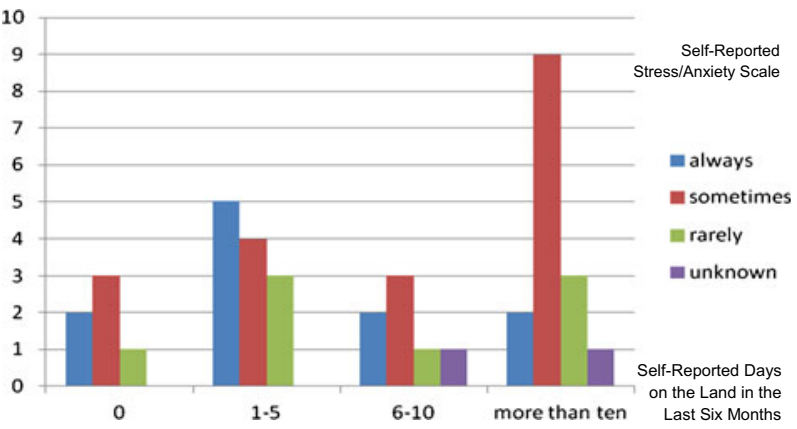

explored this relationship through research on the correlations between "time on the land" and "levels of stress and anxiety" (Fig. 4). This study sought to determine whether those who spend more time on the land experienced less stress than those who are less active on the land. There was only a limited statistical correlation (0.19) which is contradictory to qualitative data carried out on the same theme. In another community, research revealed only a minor difference in selfreported health status (a proxy for well-being) among those who had visited the land for healing or therapeutic purposes and those who had not $(n=120)$. Of those who had visited the land for healing purposes during the study year, $82 \%$ reported their health as good or excellent; the percentage was just slightly lower (77 \%) for those who had not made any visits in the study year.

The environment is also conceptualized as a threat by some northern scholars. Much of the research ongoing in the north on climate change and other environmental issues may serve to construct or perpetuate this negative interpretation of environmental conditions in some northern communities. In the ACRC project, efforts were made to determine the extent people were concerned about the environment and what environmental issues were of greatest concern. In one case study community, the results overwhelmingly imply that concern for the environment is an issue with over $70 \%$ reporting that they were "very concerned" about the state of the environment, $21 \%$ stating they were somewhat concerned and only $9 \%$ stating they were unconcerned. Another project in the western arctic focused on understanding more specifically what environmental issues (good or bad) were of concern to local communities. The environmental stresses of greatest concern to participants $(n=40)$ were those stemming from climate change and resource development (Rawluk 2012).

\subsection{Changing land and resource use patterns}

A wealth of qualitative research emphasizes the importance of land and resource use activities to the well-being of arctic Indigenous peoples. As the stresses of contaminants, climate change and resource development increase, many of those who depend on the land for their livelihood alter their land and resource use activities in order to cope, manage or adapt to these conditions. Many land and resource use patterns are highly flexible and adaptive; northerners have always had to deal with significant variability in the abundance and distribution of wildlife, fish and plants valued as food, and weather. Some scholars suggest the impacts resulting from climate change are among the greatest threats and are likely to lead to many kinds of changes in northern communities. Other IPY research alludes to perceptions that resource development is a greater threat and influence over contemporary land and resource use patterns including hunting, fishing, trapping and berry picking. As evidenced in one Indigenous community during the ACRC project, these two issues are not exclusive of another but may have a combined or cumulative effect on circumstances of well-being. 
These changes must be seen in the context of historic patterns of land and resource use. Two major IPY projects led by Andrews and Friesen provide a valuable long term perspective. These projects aimed to unravel historic practices of the Dene, Thule (Inuit) and Gwich'in people of the Northwest Territories, Nunavut and Yukon. The oral histories of northern Indigenous peoples, that are thought to date back thousands of years to time immemorial or when the land and people were created, play an important role in these and other projects. The Mackenzie River ramparts near Fort Good Hope, for example, are said to have been created by a Slavey hunter-Wichididelle, who threw rocks at a giant beaver. "His arrows can still be seen in the river. They'll remain this way until the end of time" (Andrews 2000: 32). Arrow artifacts found at melting ice patches near the community of Tulita through the IPY project led by Andrews suggest at least a 350 year history of Dene hunting in this area.

TK is not only critical to learning about the past but is vital to understanding changes in the present. Through a combination of archeological and TK research, new understandings have been developed about Thule Inuit migration from Alaska through the eastern Arctic and details about early Inuit life in coastal regions across the arctic during the cooling period of the little ice age. The Circumpolar Flaw Lead Project led by Barber, devoted one of its 10 science teams to studying the knowledge of residents from three Inuit communities adjacent to the flaw lead. The direct involvement of both elders from the Inuvialuit Settlement Region and scientists resulted in an increased understanding of flaw lead ice dynamics and their significance to the health and distribution of marine mammals including those valued for food and cultural practice by Inuvialuit. The Inuit Sea Ice Use and Occupancy Project (ISIUOP), led by Aporta, built on previous sea ice research in Nunavut and Nunavik communities with the aim of understanding more about the effects of climate change on arctic icescapes. Similarly, efforts were made to understand the spatial effects of climate on vegetation (including treeline) communities and the consequent effects on community food systems in the project led by Harper (Impacts of a Changing Arctic Tree Line). The Tr'ondëk Hwëch'in focused on documenting their understandings of climate change which include both observations of climatic effects, interpretation of the significance of those effects as well as strategies for adaptation (Table 3).

Place names or toponyms of both landscapes and icescapes provide a spatial or geographic perspective on the relationship of northern peoples to particular places. Place names can be critical to understanding climate change but also important for adaptation and resilience to

Table 3 Observations of climate change and effects in the traditional territory of the Tr'ondëk Hwëch'in

Warmer winter temperatures of $5-10^{\circ}$, which affect trappers (furs not primed), ice road conditions, and creates a change in the lifestyle and psyche of a northerner.

A 1-2 week shift in animal mating/rutting seasons later into the fall, affecting hunting seasons, and quality of meat.

Melting permafrost resulting in large frost slumps and erosion.

This affects travel and gathering abilities, water quality, and land value.

Less predictable weather, which can erode confidence in traditional knowledge and traditional knowledge holders.
Increasing brush and vegetation growth-not only thicker, but in higher altitudes and further north. This may create more food for animals such as moose, but could choke out other plants, such as lichens for caribou. This also makes travel more difficult in the bush.

New species such as cougar, deer, some birds and unidentified insects.

Declining numbers and quality of local salmon stocks, which has serious consequences for health, income, and lifestyle. 
effects of melting sea ice (Aporta 2009). Inuit use place names to read the ocean ice in ways that ensure safe and productive hunting (Fig. 5).

Many changes in land and resource use patterns are influenced or induced by changes to the physical environment (e.g., contaminants, melting sea ice). Some of the IPY research, however, focused on how changes in the sacred or spiritual nature of the environment are also highly influential as demonstrated through research in the community of Lutsel K'e during the Arctic Peoples: Culture Resilience and Caribou project. For example, the "Old Lady of the Falls" site on the Lockhart River near Lutsel K'e has a significant influence over the relationship of the Dene to the region. In addition to its therapeutic or healing properties it has always been a source of guidance about how to deal with the uncertainties of caribou distribution and other issues of environmental change. During the cold winter, hunters are said to visit the falls to ask her for help in finding caribou. Consequently, the arrival of the caribou or their disappearance is interpreted by many elders as spiritual in nature. When the caribou do not come back, it is a sign that the caribou have been disrespected by some individuals from this and other communities. As such, change in land and resource use practices may be equally a spiritual and emotional response to changes in the land as much as they are adaptations to changes in biophysical conditions.

\subsection{Food security}

The food systems of northern communities are intertwined with the condition of northern ecosystems. The traditional and subsistence activities of hunting, fishing and gathering make
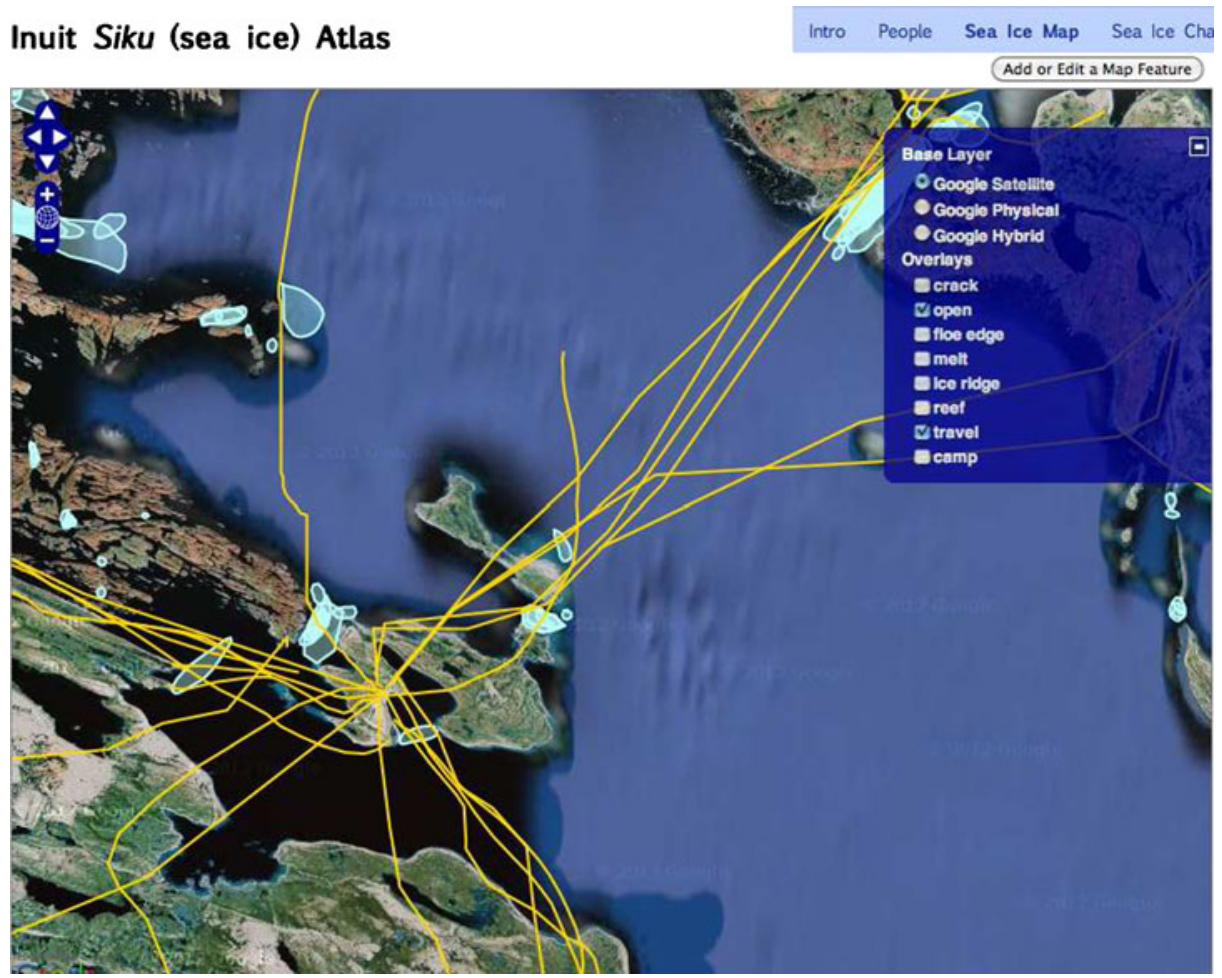

Fig. 5 Map of traditional sea ice trails near Igloolik, Nunavut (from Aporta 2011) 
an important contribution to northern diets in term of essential proteins, vitamins and other nutrients considered protective of chronic illness (Furgal 2010). Northern communities are consuming less country/traditional food in present day than in previous decades as a result of many social, economic and cultural factors as discussed in this volume. Changing environmental conditions including changes in the abundance, distribution and health of valued species also present major challenges for harvesters.

While many environmental issues (e.g., contaminants) may seem like new phenomenon, other kinds of changes are part of a well understood cycle or system of "ups and downs". Barren ground caribou (Rangifer tarandus groenlandicus) is a species of significance to many northern Indigenous peoples across northern Canada but also one characterized by cyclical variability. The most recent declines in the western Arctic have occurred in the last 15 years (Fig. 6) as shown through the IPY program on barren ground caribou led by Russell. There are many theories as to the ecological triggers and evidence points to large scale climatic factors. Not all harvesters and communities perceive caribou population changes in the same way as scientists and managers. Perceptions as well as responses to perceived declines are a function of many factors including previous experiences with caribou population decline, diversity and availability of alternative species, cost of food alternatives from the store, and the degree of engagement in governance and caribou management (i.e., settled or unsettled land claim) (Parlee and Furgal 2010;). Although communities have experienced previous periods "when the caribou did not come", the current scenario is seemingly complicated by issues of climate change and pressures on caribou and caribou habitat from resource development.

Climatic effects on wildlife population, distribution and health are critical to understanding climate related changes in harvesting and food security (Furgal 2010; Nuttall et al. 2005). The growing body of work on subsistence harvesting and land use that amassed around the theme of climate change also suggests it is becoming more difficult

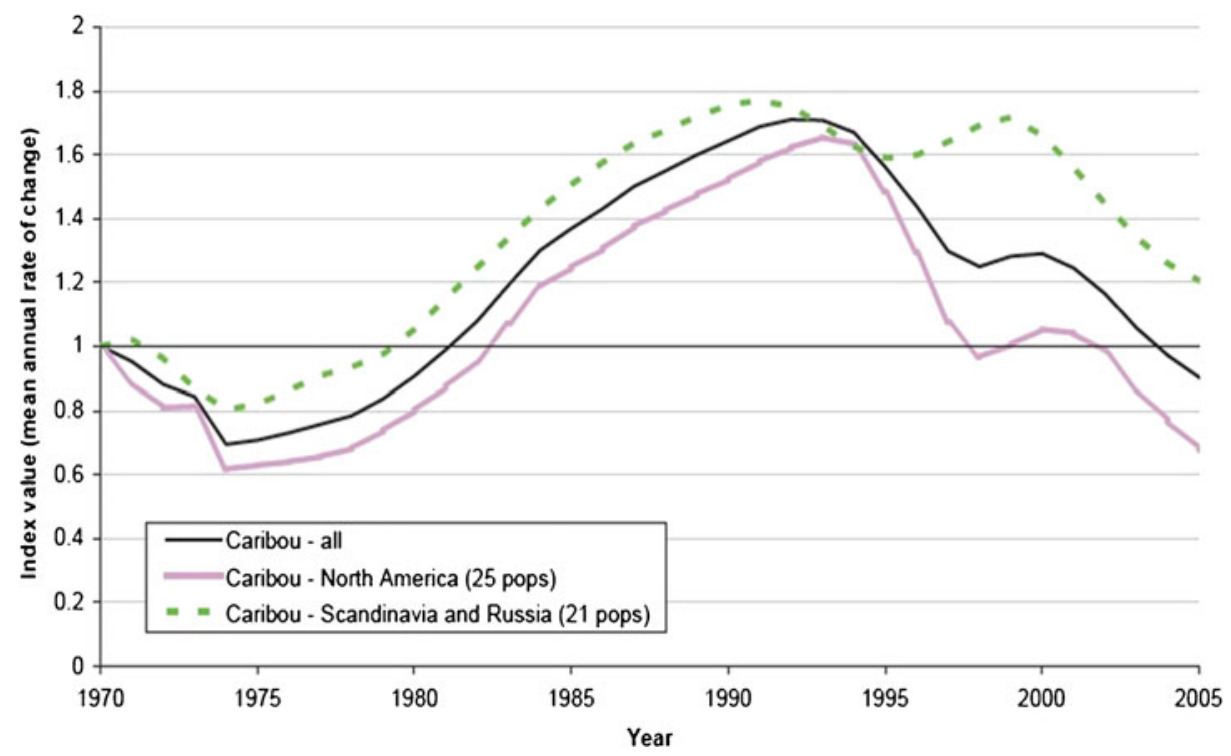

Fig. 6 Population trends for caribou (Rangifer tarandus) for North America and Scandinavia/Russia (19702005). Adapted from Russell (2012) 
for harvesters to engage in country/traditional food harvesting (Ford 2009; Ford and Furgal 2009; Pearce et al. 2010; Wesche and Armitage 2010). Case studies of marine ecosystems suggest the risks of sea ice melt as well as increased variability in weather and marine mammal distribution have had a major influence on subsistence harvesting as discussed by Barber in this issue (Riedlinger and Berkes 2000). Possible adaptations are numerous. Some community-based adaptation strategies suggested during the IPY project led by Harper include: 1) access to a community freezer, 2) increase in financial support for hunters, 3) conduct more community on the land programs, 4) share Inuit Qaujimajatuqangit (traditional knowledge) with youth, 5) learn more about healthy foods and how to prepare them (i.e., cooking classes), 6) hold more community feasts and cultural events, and 7) lower the cost of healthy food (Harper 2012).

\subsection{Poverty and development}

Poverty is a key indicator of well-being and one considered during several IPY research programs including that led by Bazely. Poverty in northern Canada is a function of many different factors including participation in the local traditional/wage economy, social supports (e.g., food sharing networks) as well as structural factors such as housing conditions and services (e.g., health services). Those individuals, households, communities and regions dealing with immediate problems of poverty (e.g., low income) are considered more vulnerable to the potential effects of climate change in that they have a limited financial safety net on which to draw in times of crisis and have limited capacity and resources to undertake adaptation measures in anticipation of climate change effects (Smit et al. 2008). Although the majority of residents are concerned about the environmental impacts of resource exploitation, employment in the mining and oil and gas sector is viewed as an immediate solution to the issues of poverty (Buell and the Ajunnginiq Centre 2006; Mathias et al. 2006). Resource development, however, is not a benefit for all as noted by research under the IPY project led by Bazely. Oil and gas exploration in the Northwest Territories has seemingly widened the gap between the haves and have-nots within and between communities as those who are able to take greater advantage of resource development opportunities profit and those already vulnerable to poverty are further marginalized. There are also predictable problems occurring with the drain of skilled labour away from communities into urban and industrial sectors.

A key misconception of resource development in the north may be the requirement of full-time employment for all. Seasonal or flexible part-time employment may be the most desirable for many families. Full-time employment has the potential to increase food insecurity as households have less time to procure country/traditional foods and become increasingly dependent on less nutritious and more costly food alternatives from the store (Todd 2010). The research seems to affirm previous research on the mixed economy and its protective role in dealing with the boom-bust effects of resource development (Usher et al. 2003).

Among the most significant and cross cutting issues of poverty in northern Canada is that of housing. Affordable housing in both urban and smaller centres is insufficient as determined through studies funded under Bazely's IPY research program. Housing insecurity is compounded by boom-bust cycles of resource development and uneven development across the territories. Homelessness along with many other issues of human insecurity (e.g., lack of mental health services), may also hinder the adaptive capacity of vulnerable populations.

Climate change will affect household dwellings, particularly those located along ocean shorelines and in areas at risk of permafrost melt and erosion, as noted by research led by Smit. The role of government in preventing or reducing these risks varies by region. In some 
areas, according to Wooten's IPY research, some municipal and territorial governments are playing a key role in reducing the risks of climate change on northern infrastructure through improvements to water and waste water treatment facilities and programs. In Nunavut it is hoped that community and regional planning will begin to take greater account of the constraints imposed by the physical landscape including coastal flooding and erosion, permafrost degradation, drainage network disruptions, and slope instability.

\subsection{Community engagement and governance}

The knowledge and skills of northern Indigenous peoples are considered critical to reducing vulnerability and increasing the adaptive capacity of individuals and institutions (Smit et al. 2008). Many communities already hold extensive knowledge (TK) about the past and present that can help unravel the degree and significance of current changes.

The engagement of local communities in scientific discoveries about environmental change in the arctic is the key to building adaptive capacity in the north. Critical insights, for example, can be gained about environmental changes not previously experienced by northern Indigenous communities such as the risks to northern ecosystems and peoples from long range and point source contaminants. The lessons of scientific research and communication on northern contaminants, however, have highlighted the complex ways in which northern communities interpret and use scientific information. This was a major consideration in the IPY research led by Simard in Nunavik.

Investigations of the linkages and synergies between western science and local and TK is important to understanding the resilience of communities to ecological phenomena previously experienced (e.g., caribou population decline) and those that are emergent (e.g., extensive permafrost melt). Adaptive capacity, although grounded in TK is also built through knowledge sharing with scientists, governments and other decision-makers (e.g., industry) involved in managing environmental change. The uptake of such knowledge by northern institutions including councils, local and regional governments as well as industry is vital to both social and social-ecological resilience. Community and regional northern governments are among the most critical leaders in ensuring the resilience of northern peoples to the stresses of resource development and climate change. There is a tight feedback loop between local land users (e.g., hunters) and regional governments, who are arguably the most sensitive to the needs of local people. Regional governments are able to make a wide range of decisions about the determinants of adaptive capacity and thus can enhance rather than detract from efforts being made by individuals and communities. Such decisions are made more complex given the other social, economic and political changes underway in the north which may be viewed as equally or more important to northern sustainability. The onus cannot be on northern peoples alone as northern institutions are bolstered and constrained by decisions made at much larger scales as noted by many IPY projects as well as previous research on adaptation and institutions (Armitage et al. 2008). Cooperation must occur between institutions at multiple scales including local, regional, territorial, national and circumpolar organizations.

\section{Conclusions and directions for future research}

Northern communities have long considered the lands and resources around them as key to their well-being. Many Inuit, Dene, Métis and other northern peoples recognize the importance of respectful and reciprocal relations between themselves and the water, fish, wildlife 
and other beings of their natural world which are imbued with sacred or spiritual significance. Beliefs that people and the animals are related like families, that the "land is alive" and cannot really be managed by people, are described in oral histories documented throughout the north, particularly in First Nations communities. In this context, research is irrelevant; the experience of environmental change is deeply personal and spiritual in nature and can really only be understood through lived experience and the development of long term respectful social and social-ecological relations.

Other aspects of well-being in the context of environmental change are more easily understood. For example, IPY research on contaminants, resource development and climate change have revealed specific changes in the condition of the land, water and wildlife which have implications for the food security and land and resource use. The Canadian IPY program intended to fund research on this and other themes. More than 15 research projects in the regions and territories of Yukon, Northwest Territories, Nunavut, Nunavik, and Nunatsiavut contributed to our understanding of well-being through collaborative research with over 50 northern and Indigenous communities (Tables 1 and 2). These studies were structured around the concepts of vulnerability, resilience, and human security, leading to a dynamic understanding of well-being and the extent to which northern peoples are relating, responding and shaping their futures.

Many northern communities are faced with circumstances of poverty that are rooted in Canadian histories of colonialism and socio-political marginalization. Some social problems (e.g., poor housing, food insecurity) are likely to be exacerbated by contaminants, climate change, large scale resource development activities and the stresses they place on families, communities and environments. Despite this concern, local communities may have a different view of their own individual circumstances as well as the "threats" of environmental change. As an example, recent changes in caribou populations defined by some scholars as a significant environmental problem are perceived by some communities as part of the natural cycle of caribou "coming and going". Similarly, climate change may be perceived as a benefit rather than a threat by some northern communities. Some northern organizations are concerned that the climate change adaptation discourse over-emphasizes and implies action on the part of those most affected rather than focusing on the causes of the environmental harms. "The message has to be conveyed to the rest of the world that, ultimately, what happens in the North will affect their lives and they too will have to adapt to climate change" (Nunavut Tunngiavik Inc. 2005).

Although there are many socio-economic and cultural factors which influence land and resource use, climate change may be a major compounding environmental factor, particularly in coastal areas of Nunavut and the Inuvialuit Settlement region where melting sea ice, erratic weather events and changes in the stability of landscapes (e.g., erosion, slumping) are leading to increased risks for hunting, fishing and travel as shown by research led by Aporta. Communities are not only observing and responding to indicators of physical changes in the environment but may also be responding to indicators of a spiritual nature. For example, irresponsible or disrespectful behaviour towards the land as a result of resource development is of concern to many communities.

An important lesson of the IPY program surrounds best practices of community collaboration and engagement in both research and decision-making about issues of arctic sustainability. While some projects involved very successful collaborations, other collaborations were challenged by a variety of theoretical, methodological and administrative issues. Although the extent of northern engagement varied from project to project, knowledge translation was an essential component of all northern projects. Further research is needed on many issues of well-being that are not explicitly related to issues of 
environmental change but may be viewed as more explicitly social, economic or political in nature. Research beyond the paradigm of TK that is more inclusive of Indigenous youth is also seen as critical given the increase of children and youth populations in northern communities.

Research during the IPY program advanced our understanding of well-being on select issues but there is more research needed. While important advances have been made, there continues to be a disproportionate investment in natural science versus social science research. Such an imbalance in knowledge available about the arctic may be unduly perpetuating perceptions of the arctic as an empty frontier of global interest rather than a homeland valued by northern peoples and Canadians. Further studies and efforts on the part of scientists to reconcile natural science research outcomes with socio-economic realities of northern communities will also contribute towards the capacity of communities to achieve well-being in the context of arctic environmental change.

Open Access This article is distributed under the terms of the Creative Commons Attribution License which permits any use, distribution, and reproduction in any medium, provided the original author(s) and the source are credited.

\section{References}

Abele F (1997) Traditional knowledge in practice. Arctic 50(4):iii-iv

Abele F (2009) Northern development: past, present and future. In: Abele F, Courchene T, Seidle L, St.-Hilaire F (eds) Northern exposure: people, powers and prospects in Canada's North. The Institute on Public Policy Research, Montreal

ACIA (Arctic Climate Change Impact Assessment) (2004) Impacts of a warming arctic-arctic climate impact assessment. Cambridge University Press, Cambridge

Adelson N (1998) Health beliefs and the politics of Cree well-being. Health 2(1):5-22

Andersen T, Poppel B (2002) Living conditions in the arctic. Soc Indic Res 58(1):191-216

Andrews T (2000) Rakekee Gok'e Godi: places we take care of. In: S. H. P. a. S. J. W. Group (ed) Yellowknife prince of Wales Northern Heritage Centre

Aporta C (2009) The trail as home: Inuit and their pan-arctic network of routes. Hum Ecol 37:131-146

Aporta C (2011) Shifting perspectives on shifting ice: Documenting and representing Inuit use of the sea ice. The Canadian Geographer 55(1):6-19

Armitage DR, Plummer R, Berkes F, Arthur RI, Charles AT, Davidson-Hunt IJ, Diduck AP, Doubleday NC, Johnson DS, Marschke M, McConney P, Pinkerton EW, Wollenberg EK (2008) Adaptive co-management for social-ecological complexity. Front Ecol Environ 7(2):95-102

Axworthy L (2001) Human security and global governance: putting people first. Glob Gov 19:19-23

Berkes F (2008a) Sacred ecology. Routledge, New York

Berkes F (2008b) Sacred ecology. Traditional ecological knowledge and resource management. Taylor \& Francis, London

Berkes F, Jolly D (2001) Adapting to climate change: social ecological resilience in a Canadian Western Arctic Community. Conserv Ecol 5(2)

Berkes F, Colding J, Folke C (2000) Rediscovery of traditional ecological knowledge as adaptive management. Ecol Appl 10(5):1251-1267

Berkes F, Huebert R, Fast H, Manseau M, Diduck A (eds) (2005) Breaking ice: renewable resource and ocean management in the Canadian North. University of Calgary Press, Calgary

Billson JM (2001) Inuit dreams, Inuit realities: shattering the bonds of dependency. Am Rev Can Stud 31(1-2):283299

Bjerregaard P, Kue Young T, Dewailly E, Ebbesson SOE (2004) Review article: indigenous health in the arctic: an overview of the circumpolar Inuit population. Scand J Public Health 32(5):390-395

Boas F (1964) The central Eskimo. University of Nebraska, Lincoln

Borgerson SG (2008) Arctic meltdown: the economic and security implications of global warming. Foreign Aff 87(2):63-77 
Bravo M (2006) Against determinism: a reassessment of Marcel Mauss's essay on seasonal variations. Etudes Inuit Stud 30(2):33-49

Buell M, the Ajunnginiq Centre (2006) Resource extraction development and well-being in the north: a scan of the unique challenges of development in Inuit communities. National Aboriginal Health Organization, Ottawa

Chapin FS (2005) Polar systems (chapter 25) In: Ecosystem and human well-being: current, state and trends. Millenium Ecosystem Assessment, Washington DC

Chapin FS, Hoel M, Carpenter SR, Lubchenco J, Walker B, Callaghan TV, Folke C, Levin SA, Mäler K-G, Nilsson C, Barrett S, Berkes F, Crépin A-S, Danell K, Rosswall T, Starrett D, Xepapadeas A, Zimov SA (2006) Building resilience and adaptation to manage arctic change. AMBIO J Hum Environ 35(4):198202

Christensen J (2011) Homeless in a homeland: housing (in)security and homelessness in Inuvik and Yellowknife, Northwest Territories, Canada. Department of Geography, McGill University, Montreal

Climate Change (2007) Impacts, adaptation and vulnerability contribution of working group II to the fourth assessment report of the intergovernmental panel on climate change. In: Parry ML, Canziani OF, Palutikof JP, van der Linden PJ, Hanson CE (eds) Cambridge University Press, Cambridge, p 976

Condon R (1988) Inuit youth: growth and change in the Canadian arctic. Rutgers University Press, New York

Daveluy M, Lévesque F, Ferguson J, International School for Studies of Arctic Societies (2011) Humanizing security in the arctic. CCI Press, Edmonton

Diener E (1996) Subjective well-being in cross-cultural perspective. In: Grad H, Blanco A, Georgas J (eds) Key issues in cross-cultural psychology. Swets and Zeitlinger, Liese

Diener E, Suh EM (2000) Culture and subjective well-being. MIT Press, Cambridge

Diener E, Suh EM, Lucas RE, Smith HL (1999) Subjective well-being: three decades of progress. Psychol Bull 125(2):276-302

Downie D, Fenge T (eds) (2003) Northern lights against POPs. McGill-Queen's University Press, Montreal

Duerden F (2004) Translating climate change impacts at the community level. Arctic 57(2):204

Egeland GM, Johnson-Down L, Cao ZR, Sheikh N, Weiler H (2011) Food insecurity and nutrition transition combine to affect nutrient intakes in Canadian arctic communities. J Nutr

Fleming J, Ledogar RJ (2008) Resilience, an evolving concept: a review of literature relevant to aboriginal research. Pimatisiwin 6(2):7-23

Forbes BC (2008) Equity, vulnerability and resilience in social-ecological systems: a contemporary example from the Russian arctic. Res Soc Probl Public Policy 15:203-236

Ford J (2009) Vulnerability of Inuit food systems to food insecurity as a consequence of climate change: a case study from Igloolik, Nunavut. Reg Environ Chang 9(2):83-100

Ford J, Furgal C (2009) Climate change impacts, adaptation and vulnerability in the arctic. Polar Res 28(1):1-9

Ford J, Smit B (2004) A framework for assessing the vulnerability of communities in the Canadian arctic to risks associated with climate change. Arctic 57(4):389

Freilich M (1967) Ecology and culture: environmental determinism and the ecological approach in anthropology. Anthropol Q 40(1):26-43

Furgal C (2010) Health impacts of climate change in Canada's North. In: Seguin J (ed) Human health in a changing climate: a Canadian assessment of vulnerabilities and adaptive capacity. Health Canada, Ottawa

Furgal C, Seguin J (2006) Climate change, health, and vulnerability in Canadian Northern aboriginal communities. Environ Health Perspect 114(12)

Furgal C, Jardine C, Garvin T (2010) Trends in the study of aboriginal health risks in Canada. Int J Circumpolar Health 69(4):322-332

Giri AK (2000) Rethinking human well-being: a dialogue with Amartya Sen. J Int Dev 12(7):1003-1018

Gracey M, King M (2009) Indigenous health part 1: determinants and disease patterns. Lancet 374(9683):65-75

Haalboom B, Natcher DC (2012) The power and peril of 'vulnerability': lending a cautious eye to community labels in climate change Research. Arctic 65(3)

Hansen EE (1999) Udvikling og Forsorg i Gyldendal, Gronland, Gyldendals, Boghandel. Nordisk Forlag, Copenhagen

Harper K, (ed) (2012) PPS arctic Canada (present processes, past changes, Spatio-temporal variability in the Arctic delimitation zone, Canada). In: I. P. Year (ed) Vol. Harper: 2006-SR1-CC-027, Science Reports. International Polar Year, Ottawa

Heine M, Andre A, Kritsch I, Cardinal A, the Elders of Tsiigehtchic (2001) Gwichya Gwich'in Googwandak: the history and stories of the Gwichya Gwich'in. Gwich'in Social and Cultural Institute, Tsiigehtchic, Northwest Territories

Hinzman L, Bettez N, Bolton W, Chapin F, Dyurgerov M, Fastie C, Griffith B, Hollister R, Hope A, Huntington H, Jensen A, Jia G, Jorgenson T, Kane D, Klein D, Kofinas G, Lynch A, Lloyd A, McGuire 
A, Nelson F, Oechel W, Osterkamp T, Racine C, Romanovsky V, Stone R, Stow D, Sturm M, Tweedie C, Vourlitis G, Walker M, Walker D, Webber P, Welker J, Winker K, Yoshikawa K (2005) Evidence and implications of recent climate change in northern Alaska and other arctic regions. Clim Chang 72(3):251298

Huish R (2008) Human security and food security in geographical study: pragmatic concepts or elusive theory? Geogr Compass 2(5):1386-1403

Indian and Northern Affairs Canada (2004) Measuring first nations well-being: first nations community well-being index. In: Statistics Canada strategic research and analysis. Government of Canada, Ottawa

INAC-Indian and Northern Affairs Canada (2010a) Regional variation and disparities of first nations and Inuit well-being. First Nation and Inuit Community Well-Being: Describing Historical Trends (19812006)

Indian and Northern Affairs Canada (2010b) In: Indian and Northern Affairs Canada (ed) Regional variation and disparities of first nations and Inuit well-being-first nation and Inuit community well-being: describing historical trends (1981-2006). Government of Canada, Ottawa

International Polar Year (2011) Highlights of the Canadian international polar year program. Government of Canada, Ottawa. www.ipy-api.gc.ca

Kirmayer LJ, Fletcher C, Watt R (2008) Locating the ecocentric self: Inuit concepts of mental health and illness. In: Kirmayer LJ, Valaskakis G (eds) Healing traditions: the mental health of aboriginal peoples in Canada. University of British Columbia Press, Vancouver

Kirmayer L, Dandeneau S, Marshall E, Phillips M, Williamson K (2011) Rethinking resilience from indigenous perspectives. Can J Psychiatr 56(2):84-91

Kral M, Idlout L, Minore J, Dyck R, Kirmayer L (2011) Unikkaartuit: meanings of well-being, unhappiness, health, and community change among Inuit in Nunavut, Canada. Am J Community Psychol 48(3):426438

Kruse J, Poppel B, Abryutina L, Duhaime G, Martin S, Poppel M, Kruse M, Ward Ed, Cochran P, Hanna V (2009) Survey of living conditions in the arctic (SLiCA)

Lyons N (2010) The wisdom of elders: Inuvialuit social memories of continuity and change in the twentieth century. Arct Anthropol 47(1):22-38

Mathias J, Ayles B, Blakney S, Charles T, Fast H, Irniq P (2006) Overview of the coastal zone Canada conference, Tuktoyaktuk, August 2006. Arctic 6(1):iii-vi

Nunavut Tunngiavik Inc (2005) What if winter never comes? Inuit perspectives on climate change adaptation challenges in Nunavut. Workshop report. Nunavut Tunngavik Inc, Iqaluit

Nuttall M, Symon C, Arris L, Hill B (2005) Hunting, herding, fishing, and gathering: indigenous peoples and renewable resource use in the Arctic. In: Arctic climate impact assessment. Cambridge University Press, New York, NY

Oosten J, Laugrand F (2002) Qaujimajatuqangit and social problems in modern Inuit society: an elders workshop on Angakkuuniq. Inuit Stud 26(1):17-44

Parlee B (2012) Finding voice in a changing ecological and political landscape: traditional knowledge and resource management in settled and unsettled land claim areas of the Northwest Territories, Canada. Aborig Pol Stud 2(1):56-87

Parlee B, Furgal C (2010) Communities and Caribou workshop summary report. In: Arctic peoples, culture, resilience and caribou. University of Alberta, Edmonton

Parlee B, O'Neil JD, Lutsel K'e Dene First Nation (2007) The Dene way of life: perspectives on health from the Canadian North. J Can Stud 41(3):112-133

Pearce T, Smit B, Duerden F, Ford J (2010) Inuit vulnerability and adaptive capacity to climate change in Ulukhaktok, Northwest Territories, Canada. Polar Rec 24(148):1-21

Prout S (2011) Indigenous wellbeing frameworks in Australia and the quest for quantification. Soc Indic Res $1-20$

Rawluk A (2012) Intergenerational resilience in Aklavik, Northwest Territories. Department of Resource Economics and Environmental Sociology, University of Alberta, Edmonton

Richmond CAM, Ross NA (2009) The determinants of First Nation and Inuit health: a critical population health approach. Health Place 15(2):403-411

Riedlinger D, Berkes F (2000) Contributions of TK to understand climate change in the Canadian arctic. Nat Resour Inst (Univ Manit) Polar Rec 37:315-328

Royal Commiissionon Aboriginal Peoples (1996) Gathering strength (volume iii). Ministry of Supply and Services, Ottawa

Smit B, Hovelsrud G, Wandel J (2008) Community adaptation and vulnerability in arctic regions (CAVIAR). University of Guelph, Guelph

Steckley J (2008) White lies about the Inuit. University of Toronto Press, Toronto 
Suluk TK, Blakney SL (2009) Land claims and resistance to the management of harvester activities in Nunavut. Vol. 61

Taylor J (2008) 87, 111-126. 2008. Indigenous peoples and indicators of well-being: Australian perspectives on United Nations global frameworks. Soc Indic Res 87:111-126

Todd Z (2010) Food security in Paulatuk, NT-opportunities and challenges of a changing community economy. Department of Rural Economy, Faculty of Graduate Studies and Research, University of Alberta, Edmonton

Usher PJ, Duhaime G, Searles E (2003) The household as an economic unit in arctic aboriginal communities, and its measurement by means of a comprehensive survey. Soc Indic Res 61(2):175-202

Wesche S, Armitage D (2010) As long as the sun shines, the rivers flow and grass grows: vulnerability, adaptation and environmental change in Deninu Kue Traditional Territory, Northwest Territories. In: Hovelsrud G, Smit B (eds) Community adaptation and vulnerability in arctic regions. Springer Publishing, Toronto

West C (2011) The survey of living conditions in the Arctic (SLiCA): a comparative sustainable livelihoods assessment. Environ Dev Sustain 13(1):217-235

Wilson K (2003) Therapeutic landscapes and First Nations peoples: an exploration of culture, health and place. Health Place 9(2):83-93

Wootton BC, Metcalfe C (2010) A nice cold drink: keeping water potable in Canada's North. Water Canada 2019(March/April):22-24

Young TK, Mollins CJ (1996) The impact of housing on health: an ecologic study from the Canadian arctic. Arctic Med Res 55(2):52-61 